\title{
Arctic summer sea-ice seasonal simulation with a coupled model: Evaluation of mean features and biases
}

\author{
P P Saheed ${ }^{1, *}$, Ashis K Mitra ${ }^{1}$, Imranali M Momin ${ }^{1}$, E N Rajagopal ${ }^{1}$, \\ Helene T HewitT ${ }^{2}$, Ann B Keen ${ }^{2}$ and Sean F Milton ${ }^{2}$ \\ ${ }^{1}$ National Centre for Medium Range Weather Forecasting, Ministry of Earth Sciences, Noida, UP, India. \\ ${ }^{2}$ United Kingdom Meteorological Office, Exeter, UK. \\ *Corresponding author.e-mail: saheed@ncmrwf.gov.in
}

MS received 25 January 2018; revised 23 April 2018; accepted 24 April 2018; published online 11 December 2018

Current state of the art weather/climate models are representation of the fully coupled aspects of the components of the earth system. Sea-ice is one of the most important components of these models. Simulation of sea-ice in these models is a challenging problem. In this study, evaluation of the hindcast data of 14 boreal summer seasons with global coupled model HadGEM3 in its seasonal set-up has been performed over the Arctic region from 9th May start dates. Along with the biases of the sea-ice variables, related atmosphere and oceanic variables have also been examined. The model evaluation is focused on seasonal mean of sea-ice concentration, sea-ice thickness, ocean surface current, SST, icedrift velocity and sea-ice extent. To diagnose the sea-ice biases, atmospheric variables like, $10 \mathrm{~m}$ wind, $2 \mathrm{~m}$ air temperature, sea-level pressure and ocean sub-surface temperatures were also examined. The sea-ice variables were compared with GIOMAS dataset. The atmospheric and the oceanic variables were compared with the ERA Interim and the ECMWF Ocean re-analysis (ORAP5) datasets, respectively. The model could simulate the sea-ice concentration and thickness patterns reasonably well in the Arctic Circle. However, both sea-ice concentration and thickness in the model are underestimated compared to observations. A positive (warm) bias is seen both in $2 \mathrm{~m}$ air temperature and SST, which are consistent with the negative sea-ice bias. Biases in ocean current and related ice drift are not related to biases in the atmospheric winds. The magnitude of the oceanic subsurface warm biases is seen to be gradually decreasing with depth, but consistent with sea-ice biases. These analyses indicate a possibility of deeper warm subsurface water in the western Arctic Ocean sector (Pacific and Atlantic exchanges) affecting the negative biases in the sea-ice at the surface. The model is able to simulate reasonably well the summer sea-ice melting process and its inter-annual variability, and has useable skill for application purpose.

Keywords. Arctic sea-ice; model simulation; coupled model; sea-ice verification.

\section{Introduction}

Sea-ice exists as a thin layer at the interface of the ocean and atmosphere, and is sensitive to small changes in temperature and radiative forcing. Sea-ice plays a significant role in regulating the global heat budget through high surface albedo, insulating the ocean beneath it. Formation of

Supplementary material pertaining to this article is available on the Journal of Earth System Science website (http://www. ias.ac.in/Journals/Journal_of_Earth_System_Science). 
sea-ice causes brine rejection and that increases the salinity in the ocean and the melting of sea-ice decreases the salinity which freshens the ocean. Changes in the Arctic and Antarctic seaice are one of the most direct indicators of climate change (Feltham 2015). The extensive retreat of sea-ice in the Arctic in the recent decades has been a major problem and concern for our climate system. The satellite record for the past three decades shows a sharp decreasing trend in the sea-ice extent over the northern hemisphere and the Arctic region with a maximum negative trend in the month of September (Serreze et al. 2007; Parkinson and Cavalieri 2012; Serreze and Stroeve 2015). There has not been a single monthly record high in the Arctic since 1986. Nevertheless, there have been 75 record lows during the same period (Parkinson and DiGirolamo 2016). Comiso (2006) reported a remarkable decline of Arctic sea-ice area and the extent in the winters of 2005 and 2006 and he attributed the negative sea-ice anomalies to the surface temperature anomalies and the changing wind pattern. Seaice concentration is correlated to several modes of atmospheric variability, which should be well represented in models. Liu et al. (2004) explained that the western (eastern) Arctic is positively (negatively) affected by the positive (negative) phases of Arctic Oscillation and the El Niño Southern Oscillation (ENSO). The decline of sea-ice in the Arctic contributes to the Arctic amplification but it is regulated by the Pacific Decadal Oscillation (PDO) (Screen and Francis 2016). Deser and Teng (2008) explained the effect of Northern Annular Mode (NAM) and atmospheric circulation on the sea-ice concentration. Sea-ice responds to the changes in the atmosphere and the ocean variability and vice-versa on times scales ranging from a few days to decade. The three potential dynamical pathways that link Arctic amplification to midlatitude weather are changes in storm tracks, the jet stream, and planetary waves and their associated energy propagation (Cohen et al. 2014). The changes in the Arctic have apparent relations with the weather events occurring in the tropics (Krishnamurti et al. 2014) and they attributed the rapid Arctic ice melt to the high rainfall events in association with the South Asian monsoon. Heat released from tropical monsoon convection causes the transport of large heat fluxes to the Canadian Arctic. Henderson et al. (2014) studied the variability of sea-ice with different phases of the leading mode of atmospheric intra-seasonal variability, the
Madden-Julian Oscillation (MJO) and found that the MJO modulates Arctic sea-ice regionally. The wind forcing in the Arctic Ocean increases in the reduced sea-ice scenario, which impacts on the ocean currents and the Arctic fresh water outflow (Vihma 2014).

There have been numerous investigations on the Arctic sea-ice variability and its effects on regional as well global atmospheric changes and vice-versa, using coupled ocean-atmosphere-cryosphere/earth system models. Rinke et al. (2013) used the coupled regional climate model HIRHAM-NAOSIM and investigated the atmospheric feedbacks associated with the late summer sea-ice anomalies in the Arctic and suggested that the feedbacks depend on regional as well as decadal variations in the coupled atmosphere-ocean-sea-ice system. Cassano et al. (2014) conducted a series of numerical experiment in order to study the atmospheric responses of reduced sea-ice cover and concluded that the observed atmospheric circulation anomalies was driven partly by the changes in the sea-ice in some seasons. Rae et al. (2014) conducted sensitivity study of the sea-ice using the HadGEM3 (Hadley Centre Global Environment Model version 3) model and reported that an increased atmospheric resolution reduces the sea-ice extent due to an increased pole ward heat transport. Petrie et al. (2015) investigated the large scale atmospheric circulation response to the large decline of arctic sea-ice since 2007, in the ERA-Interim re-analysis and HadGEM3 climate model experiments. Day et al. (2016) presents the description of the datasets for the Arctic from a coordinated set of idealised initial-value predictability experiments with seven general circulation models. Pemberton et al. (2017) conducted a 45 year long hind-cast of the sea-ice cover in the Baltic Sea, using NEMOLIM3.6 ocean-sea-ice model and reported that the simulated sea-ice variables, like sea-ice concentration and thickness, are comparable with the best available datasets.

Recognizing these key aspects, a better representation of sea-ice in the weather/climate models is very important. The sea-ice variables such as thickness, extent, concentration, volume, and ice drift velocity are dependent on the forcing by the atmosphere from above and also by the ocean from below. The model should comprehend the governing dynamics and thermodynamic properties of the sea-ice as part of coupled system. Among the first generation coupled models, Hadley Centre coupled model (HadCM3) (Gordon et al. 2000) could 
produce stable and realistic simulations of sea-ice variables, even though the sea-ice was modelled in relatively simple manner. The sea-ice component in the HadGEM1 (Johns et al. 2006) was more complex than that in the HadCM3. In HadGEM1, the sea-ice thermodynamics as well as dynamics were improved by absorbing the components of Los Alamos National Laboratory sea-ice model (CICE) (McLaren et al. 2006; Hunke and Lipscomb 2010). HadGEM1 resolved the sub-grid scale ice thickness distribution (ITD). The evolution of ITD was being determined by thermodynamic growth/ melt, advection, and redistribution by ridging (Thorndike et al. 1975). HadGEM3 (Hewitt et al. 2011; Keen et al. 2013) employs a fully coupled atmosphere, ocean and sea-ice models, the Met Office Unified Model atmosphere component, the NEMO (Nucleus for European Modelling of the Ocean) (Madec 2008) ocean model and the Los Alamos sea-ice model (CICE) using the OASIS coupler. For continuous model development, it is important to evaluate the model skill in the Arctic for the sea-ice related parameters (Tietsche et al. 2014, 2017).

In this study, we analyse the sea-ice variables and related ocean and atmospheric components over the Arctic Ocean from coupled hind-cast runs performed at NCMRWF, India in collaboration with Met Office UK. The seasonal runs were made for 14 northern summer monsoon seasons during 1996-2009 with a version of HadGEM3 in the seasonal set-up. The seasonal mean of seaice concentration, sea-ice thickness, sea-ice drift velocity, SST, sub-surface temperature, $2 \mathrm{~m}$ atmospheric temperature, mean sea-level pressure and $10 \mathrm{~m}$ winds for the months of July, August and September (JAS), which is the peak sea-ice melting season, for the entire period of simulation is being compared with that of the observed/re-analysis variables.

\section{Coupled model set-up and data used}

The coupled model set-up at the National Centre for Medium Range Weather Forecasting (NCMRWF) was similar to the GloSea4 system of UKMO (Arribas et al. 2011; Hewitt et al. 2015). The exact details of the implementation is given in Mitra et al. (2013). This model is being further jointly studied/developed for monsoon prediction for South Asia region. The core model is the version of coupled UKMO (HadGEM3), which includes a range of specific model configurations incorporating different levels of complexity, but with a common physical framework. In the HadGEM3 (Hewitt et al. 2011; Peterson et al. 2015) model framework, the UM atmospheric model, NEMO ocean model and the CICE sea-ice models are being coupled through the OASIS coupler. The coupled model at the NCMRWF employs the atmosphere model with a spatial resolution of $1.875 \times 1.25^{\circ}$ in the horizontal, having 85 layers in the vertical ( 50 levels are below $18 \mathrm{~km}$ ), the NEMO ocean model in the ORCA tri-polar grid configuration, which has $1 \times 1^{\circ}$ horizontal resolution in mid-latitudes and enhanced meridional resolution near the equator $\left(0.33^{\circ}\right.$ at the equator $)$, giving 75 layers in the vertical with a very fine resolution in the upper ocean $(1 \mathrm{~m}$ resolution near the ocean surface. The CICE (version 4.1) model (Lipscomb and Hunke 2004) configuration used is based on the zero-layer approximation of (Semtner 1976), which has five ice thickness categories. The sub-grid scale ITD is simulated in such a way that the ice pack in the each grid cell is divided into five thickness categories. Even though the standard CICE model employs multilayer ice model (Bitz and Lipscomb 1999), in HadGEM3 the growth and melting of seaice are calculated by using the zero-layer thermodynamic model of (Semtner 1976) with one layer of snow and one layer of ice in the vertical. The development of global sea-ice 6.0 configuration for the Met Office global coupled model GC2.0 is explained by Rae et al. (2015). Here the start date for our coupled model runs is 9 May, and we did hindcast runs in NCMRWF HPC system from 1996 to 2009. The coupled NCUM was integrated for six months stretching up to October for each of the above-mentioned years. Results for July, August and September (JAS) period are discussed in this study.

The monthly mean sea-ice concentration data is taken from the Met Office Hadley Centre's seaice dataset HadISST1 (Rayner et al. 2003) which is having $1 \times 1^{\circ}$ spatial resolution. The monthly mean sea-ice thickness and sea-ice motion vectors data are taken from the GIOMAS dataset (Zhang and Rothrock 2003), having a spatial resolution of $1 \times 1^{\circ}$. Apart from the sea-ice variables, the atmospheric variables, $2 \mathrm{~m}$ temperature, sea level pressure, atmospheric vertical temperature and atmospheric $10 \mathrm{~m}$ winds were taken from the ERA INTERIM dataset having a spatial resolution of $\sim 1 \times 1^{\circ}$ (Dee et al. 2011). The monthly mean sea surface temperature (SST) is taken from the Reynolds's SST (Reynolds et al. 2007) datasets 


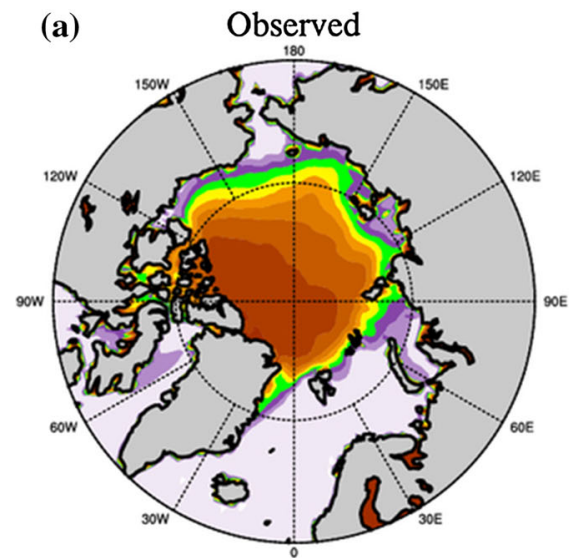

(b)
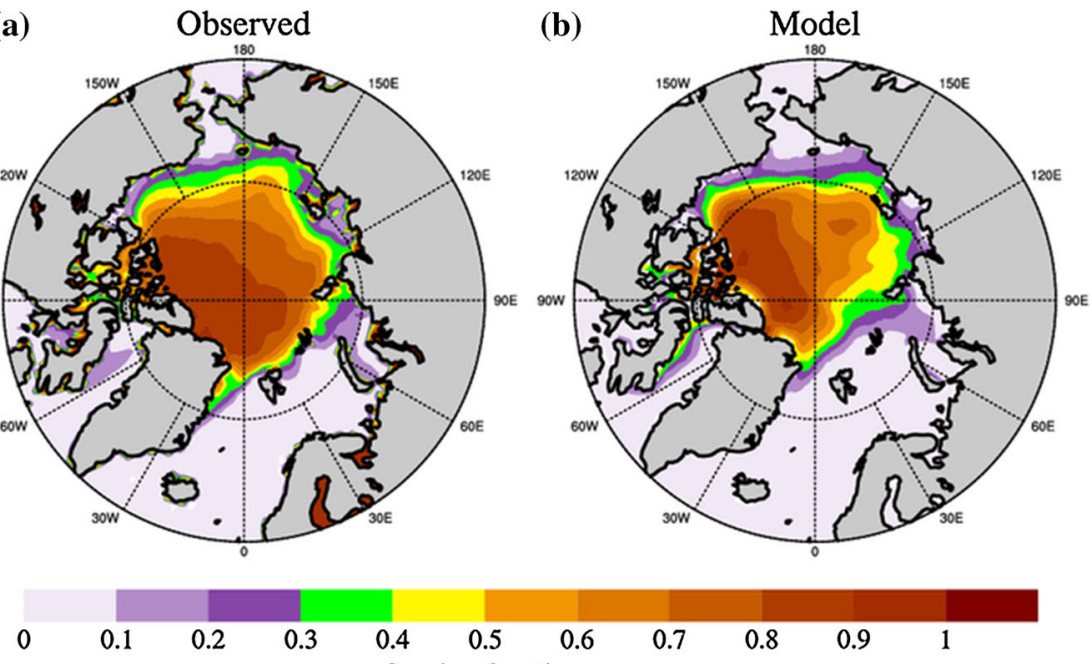

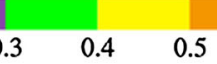

Sea ice fraction
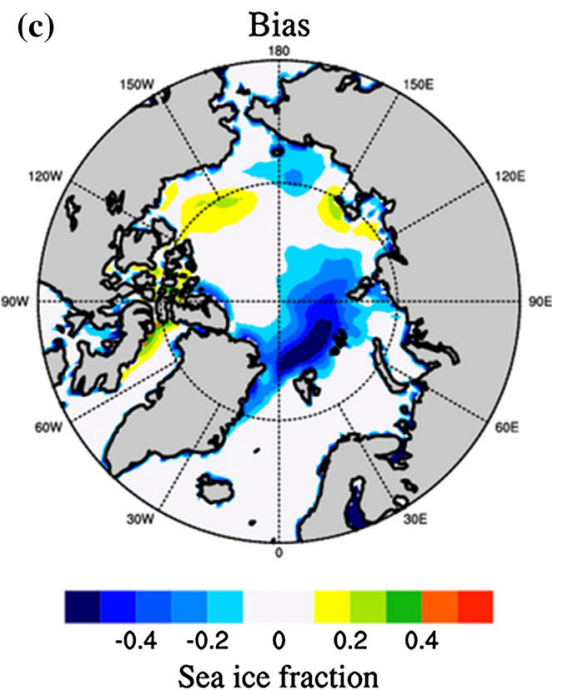

Figure 1. Mean sea-ice concentration (JAS) during 1996-2009.

with a spatial resolution of $0.25 \times 0.25^{\circ}$ and the monthly mean ocean vertical temperature is taken from the ECMWF Ocean Reanalysis (ORAP5) datasets (Balmaseda et al. 2013) having a spatial resolution of $0.25 \times 0.25^{\circ}$. All the variables are interpolated to a common spatial resolution of $1 \times 1^{\circ}$ before computing the biases.

\section{Results and discussion}

For the Arctic region sea-ice related variables will be discussed for the July-September (JAS) 3 months period. The peak summer for the northern polar region is associated with this JAS months, during which the sea-ice extent and concentration is usually minimum. This period covers the complex melting and related decreasing of seaice extent which has to be examined in coupled model simulations. Any bias during the period will reveal the weakness of the model in simulating sea-ice related processes. Sea-ice concentration is an important variable to study in model simulations. In the model grid box the relative area within the grid (ice fraction) represented indicates the sea-ice concentration. Similar quantities are also available from sea-ice observations in HadISST data (Rayner et al. 2003). Figure 1 shows the mean Arctic summer seasonal (JAS) sea-ice concentration in fraction expressed in a scale of $0-1$ during the simulation period. In observations, the sea-ice is mostly confined to the Arctic Circle. A wide-spread of $0.8-1$ fraction sea-ice concentration is seen in the observation off Greenland through the Lincoln Sea reaching the southern part of the Beaufort Sea with a northern extent reaching till the center of the Arctic Circle. The model also produces a similar pattern of sea-ice concentration covering very similar regions as seen in the observations. However, its northern extent is limited to the Lincoln Sea and not reaching to the center of the Arctic Circle as seen in the observation. The model could simulate the sea-ice concentration reasonably well in the Arctic Circle. One region of negative bias seen is in the east of Greenland and the north of Barents and Kara Sea. The model is underestimating the sea-ice concentration by around $20-60 \%$.

Figure 2 shows the seasonal (JAS) mean sea-ice thickness over the Arctic Ocean during the simulation period. The sea-ice thickness is seen to go up to $4 \mathrm{~m}$. In the observation, there are two regions with maximum ice thickness distributions. One is off Greenland and the other is off Queen Elizabeth islands. There is a spread of $2 \mathrm{~m}$ thick sea-ice all the way from the south eastern Arctic Circle, off Greenland, through the Lincoln Sea to the Beaufort Sea and a $1 \mathrm{~m}$ thick sea-ice spread all over the Arctic Circle southwards. The sea-ice thickness in the model shows a maximum value of $2 \mathrm{~m}$ around the same regions, where a maximum was seen in observations. Another patch of $1 \mathrm{~m}$ thick sea-ice is seen from the southwestern Arctic Circle to the southern Beaufort Sea. The difference between the model and the observation shows a large negative bias all over the Arctic Circle. The maximum negative bias of $3 \mathrm{~m}$ is seen off Greenland. A negative bias of $1-2 \mathrm{~m}$ is spread all over the Southern Arctic Ocean to the South West Arctic Ocean, in the Lincoln Sea and a negative bias of $1 \mathrm{~m}$ all over the Arctic Ocean. 

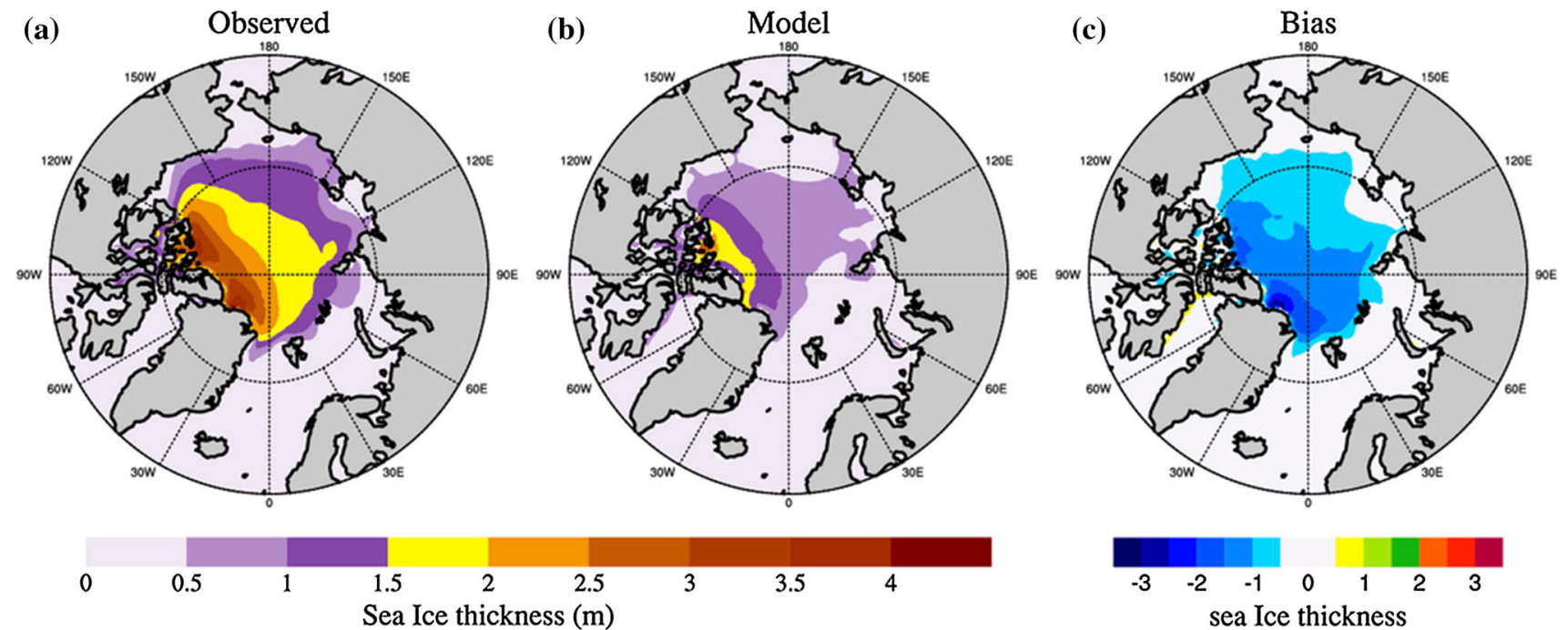

Figure 2. Mean sea-ice thickness (JAS) during 1996-2009.

The observed seasonal mean ocean surface currents (figure 3) in the Arctic Ocean depict the main circulation features. The clockwise Beaufort Gyre and the transpolar drift are seen clearly. The model is also able to simulate the main features seen in observations. There are biases seen over the Greenland Sea and the Arctic Ocean. There is an anticlockwise pattern in the bias, which diminishes the intensity of the Beaufort Gyre in the model. The biases in the surface circulation reflect in the seasonal mean ice drift as well (figure 4). The transpolar drift which pushes the sea-ice towards Greenland helps form thick multi-year ice. The observed sea-ice drift shows a strong drift towards Greenland and also towards the Queen Elizabeth islands, which helps for the formation of multiyear sea-ice whereas in the model, there is an ice drift away from Greenland coastal seas, which could be one reason for the negative bias in the sea-ice thickness in the model related to possible absence of multiyear ice. A weakened transpolar drift results in a weak ice drift towards the Greenland region and hence that could restrict the formation of the multiyear ice in the model. Similar results have been reported from a model inter-comparison study of four global coupled climate models (Tietsche et al. 2014), which indicate that the biases of seaice in coastal regions are linked to sea-ice drift errors. The ice drift is closely related to the ocean currents. The observed ice drift and current data used here is from GIOMAS, which could be having some uncertainty in Fram Straight region. Better re-analysis data is required for the polar regions.
Next, we examine the biases in the $2 \mathrm{~m}$ air temperature in model simulations (figure 5 ). There is a positive (warm) bias of $2^{\circ} \mathrm{C}$ in the mean air temperature at $2 \mathrm{~m}$ seen in the same regions as the sea-ice thickness biases off Greenland extending up to the southern extend of Beaufort Gyre. This positive $2 \mathrm{~m}$ air temperature bias is consistent with the negative sea-ice thickness bias in the region. The larger atmospheric wind pattern at $10 \mathrm{~m}$ height over the entire Arctic (figure 6) shows an organized anti-cyclonic (vertically sinking motion) bias in the model in the eastern Arctic extending from the central to the Laptev Sea, which is indeed associated with a positive bias in mean sea level pressure in the same region (figure 7). It is seen from the biases of $10 \mathrm{~m}$ winds and the surface ocean currents, that the biases in currents are not directly related to the biases in winds. Usually, the atmospheric forcing like winds and fluxes driving the ocean model produces the biases in upper-ocean. Biases in ocean current (related ice drift) is not similar to wind biases. Therefore, it is possibly that other processes like sea-level gradient, thermohaline gradient and the remote forcing could be other sources related to surface current biases.

The mean sea surface temperature (figure 8) gives a positive model bias in the same region, where a negative bias in the sea-ice concentration was seen. The similar biases are found in the subsurface temperature in the $12 \mathrm{~m}$ depth (figure 9) and also in the $30 \mathrm{~m}$ (figure 10). The magnitude of the sub-surface biases is seen to be gradually decreasing, which is consistent with sea-ice biases in upper layers. The maximum positive sea-surface 

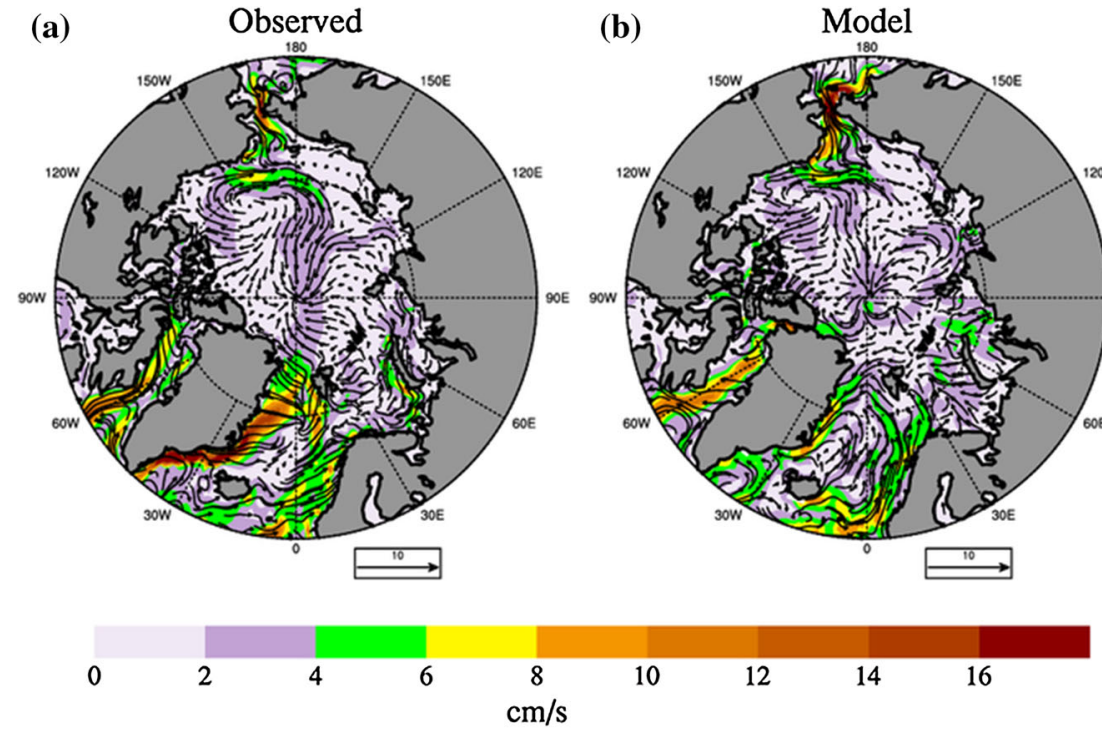
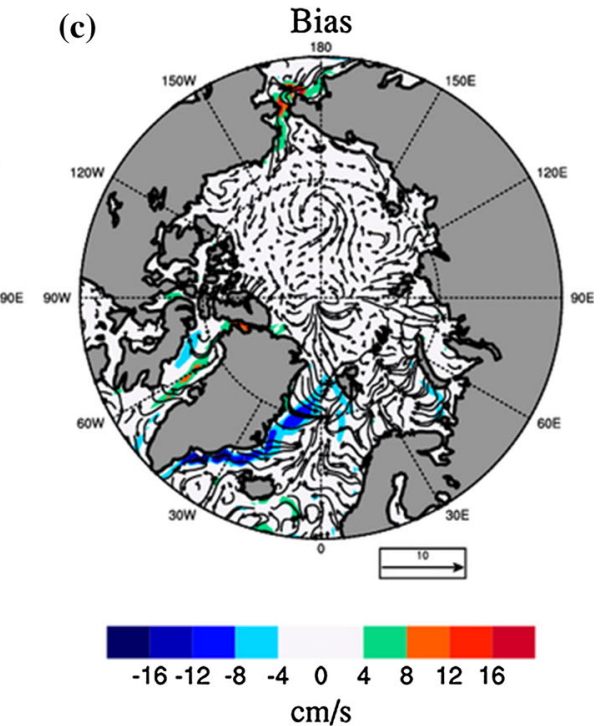

Figure 3. Mean surface current (JAS) during 1996-2009.

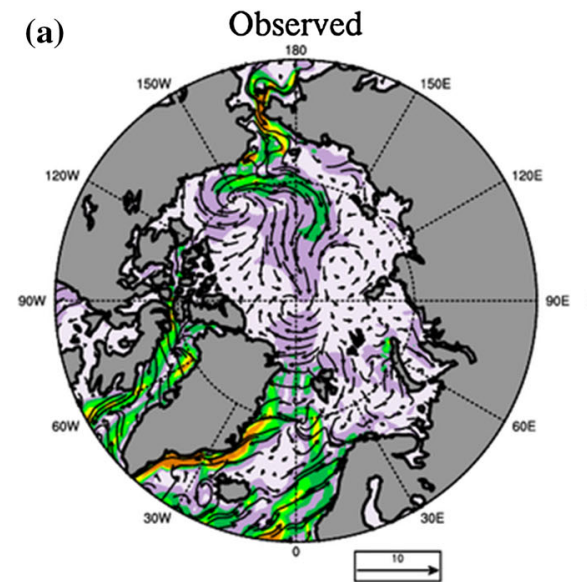

(b)
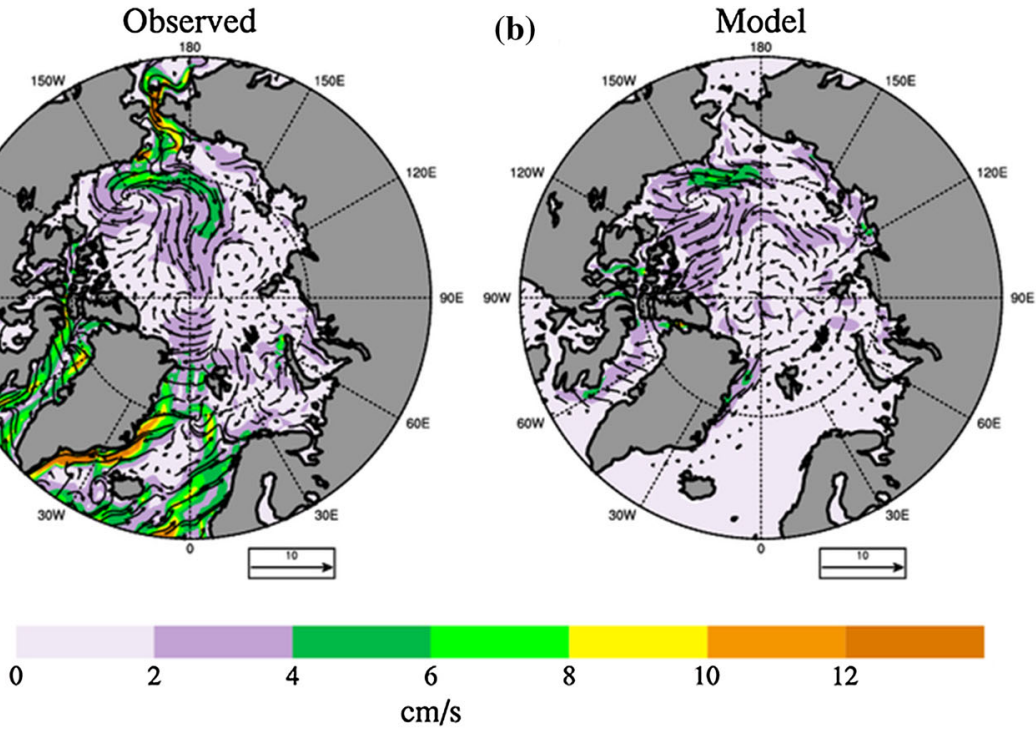
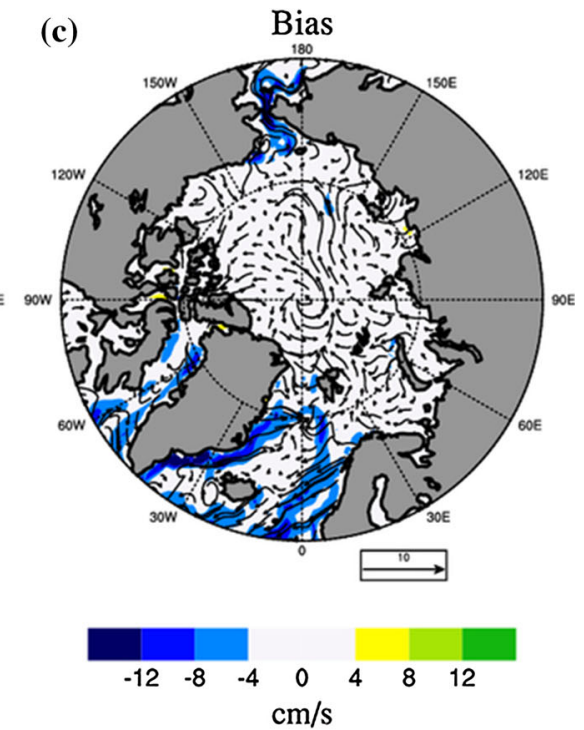

Figure 4. Mean sea-ice drift (JAS) during 1996-2009.

temperature bias at surface agrees with negative sea-ice concentration bias there. Therefore, from the sub-surface temperature biases at 12 and $30 \mathrm{~m}$, it is not possible to conclude if the negative sea-ice bias is related to the sub-surface warm biases coming from deeper waters. To examine further, we looked at deeper sub-surface temperature biases up to $500 \mathrm{~m}$ in model (figure 11). The Arctic Ocean region is divided into western $\left(0-180^{\circ} \mathrm{W}\right.$, $\left.60-90^{\circ} \mathrm{N}\right)$ and eastern $\left(0-180^{\circ} \mathrm{E}, 60-90^{\circ} \mathrm{N}\right)$ sectors for analysis purposes. There is a positive warm bias in the entire first $50 \mathrm{~m}$ of the upper ocean (figure 11a and b) in both the sectors of Arctic Ocean. Below $200 \mathrm{~m}$, the deeper sub-surface biases show a positive warm one in western sector and a mild positive warm bias in the eastern sector. This shows that there is a possibility of deeper warm sub-surface water in western sector (Pacific and Atlantic exchanges), which could be affecting the negative biases in the sea-ice at surface.

Since the model set up was for seasonal scale simulation, we examined the skill of the model in capturing the inter-annual sea-ice extent variability in model and observations. Figure 12(a) shows a reasonably good simulation of the sea-ice extent in the model. The model is able to capture the summer sea-ice melting well. The correlation for the study period compared to observation is 0.94 , 

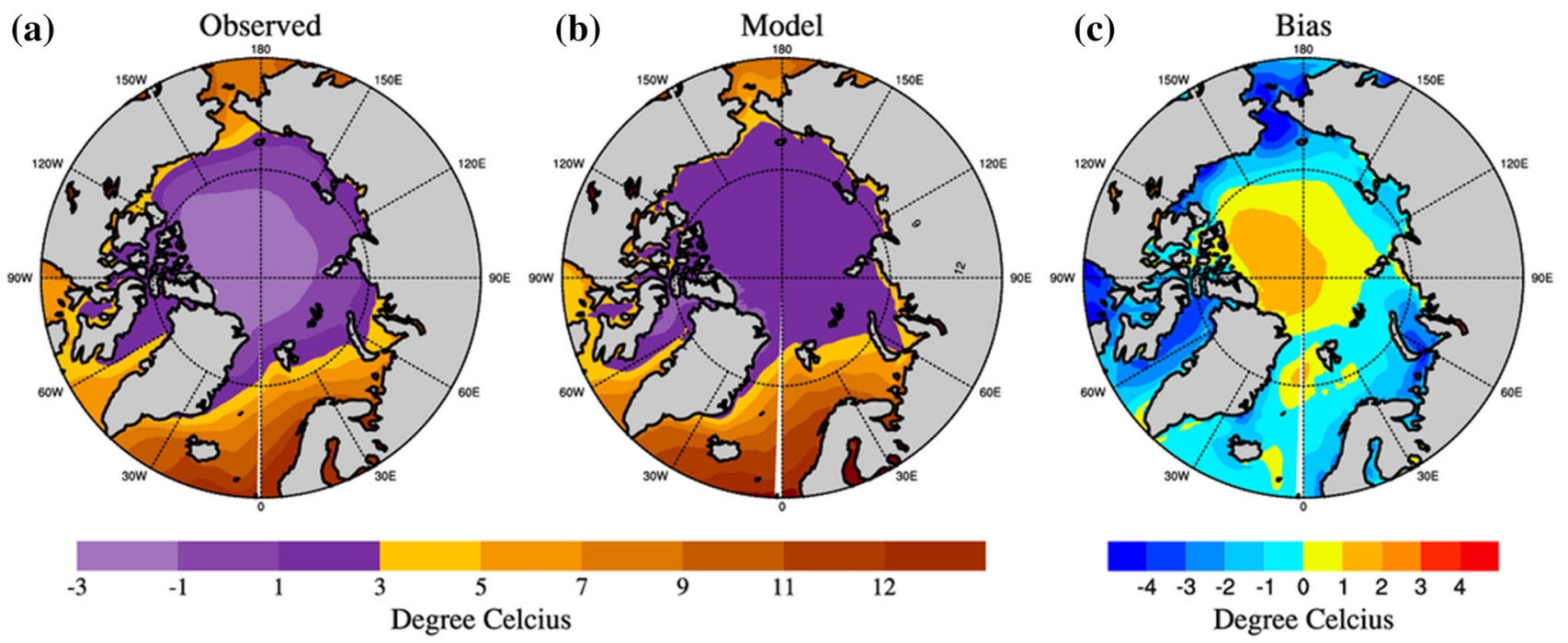

Figure 5. Mean air temperature at 2 m (JAS) during 1996-2009.
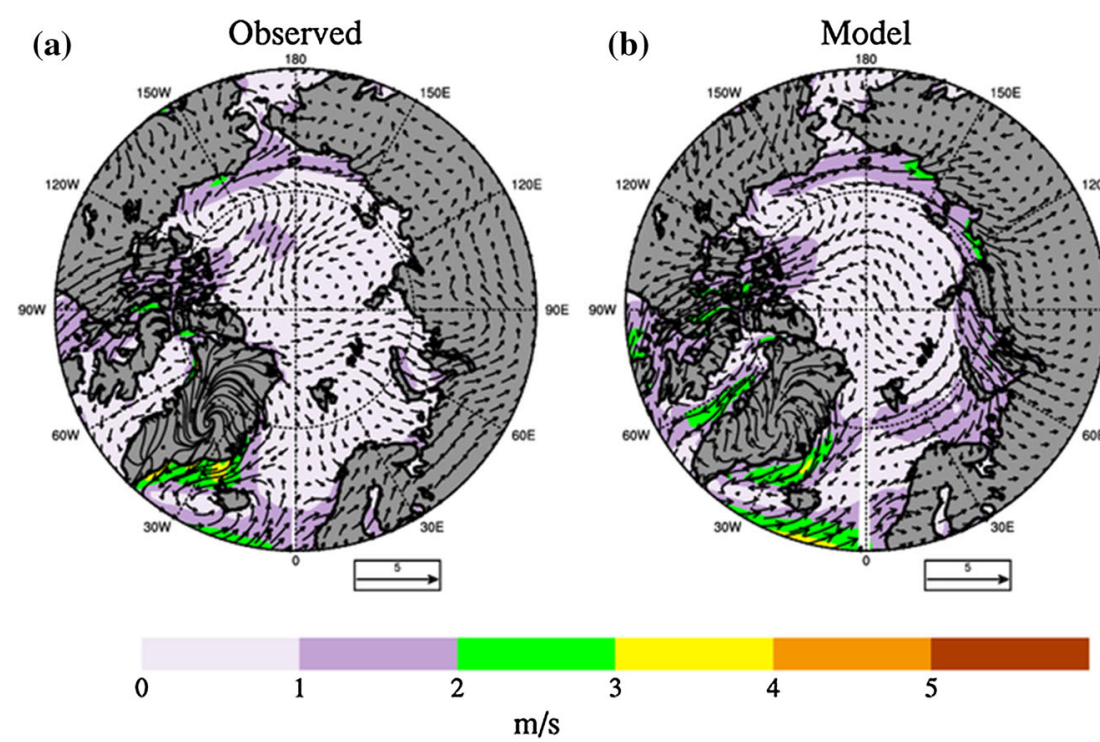

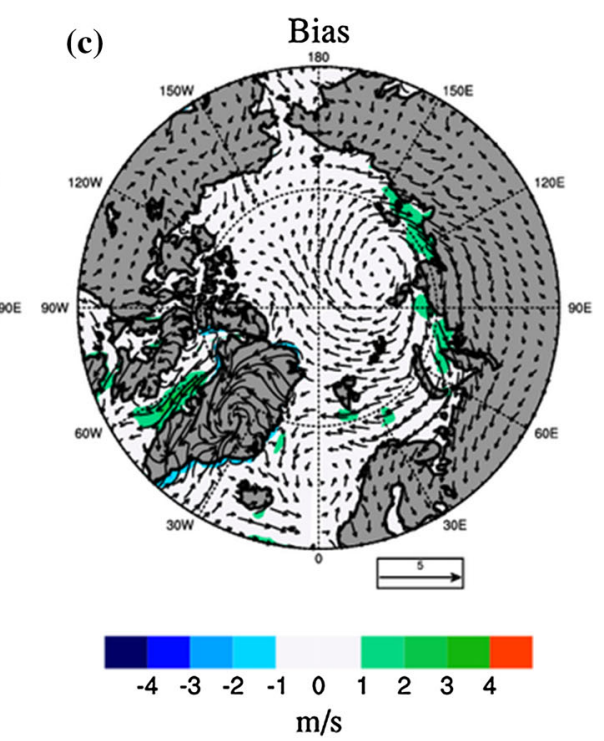

Figure 6. Mean $10 \mathrm{~m}$ wind (JAS) during 1996-2009. which is a good skill. Figure 12(b) shows the skill of the model in capturing the sea-ice extent anomaly (departure from the respective mean) for the JAS season for the simulation period. The model is able to capture the inter-annual variability of the sea-ice extent anomaly. In most of the years the sign of the anomaly is in correct direction. Hence potentially, this model is useful in extended/seasonal prediction of sea-ice extent for Arctic in JAS season.

\section{Summary and future works}

Coupled weather/climate models have to include a realistic sea-ice module to take care of the interactions with the polar regions. In this study, the seasonal set up (GloSea4) of the HadGEM3 global coupled model was used to produce seasonal hind-cast data for northern summer. Sea-ice related variables were studied for the Arctic region from the model simulations. Along with the biases of the sea-ice variables, related atmosphere and oceanic variables were also examined. Seasonal mean/biases of sea-ice concentration, sea-ice thickness, Arctic Ocean current, SST, ice-drift velocity and sea-ice extent were studied. Atmospheric variables like, $10 \mathrm{~m}$ wind, $2 \mathrm{~m}$ air temperature, sea-level pressure and ocean sub-surface temperatures were also examined to diagnose the sea-ice biases. The model could simulate the sea-ice concentration and 

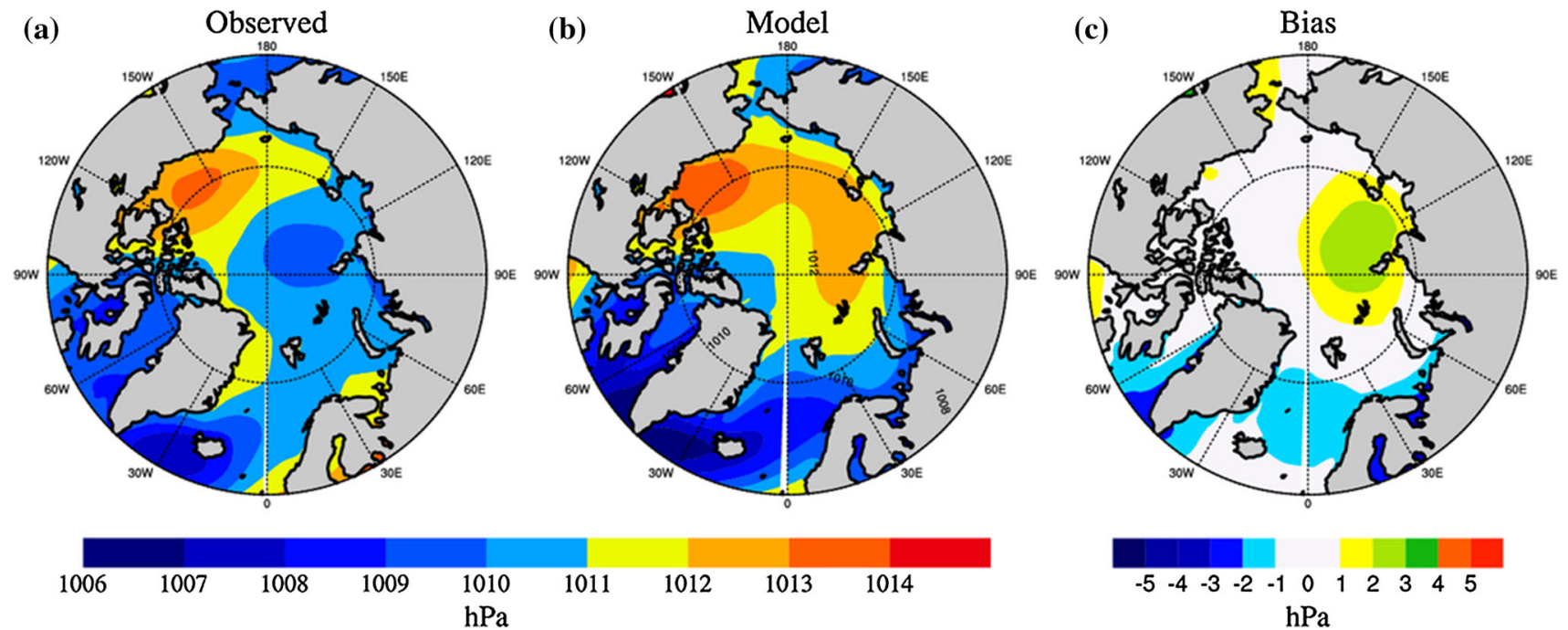

$\begin{array}{lllllllllll}-5 & -4 & -3 & -2 & -1 & 0 & 1 & 2 & 3 & 4 & 5\end{array}$ $\mathrm{hPa}$

Figure 7. Mean sea level pressure (JAS) during 1996-2009.
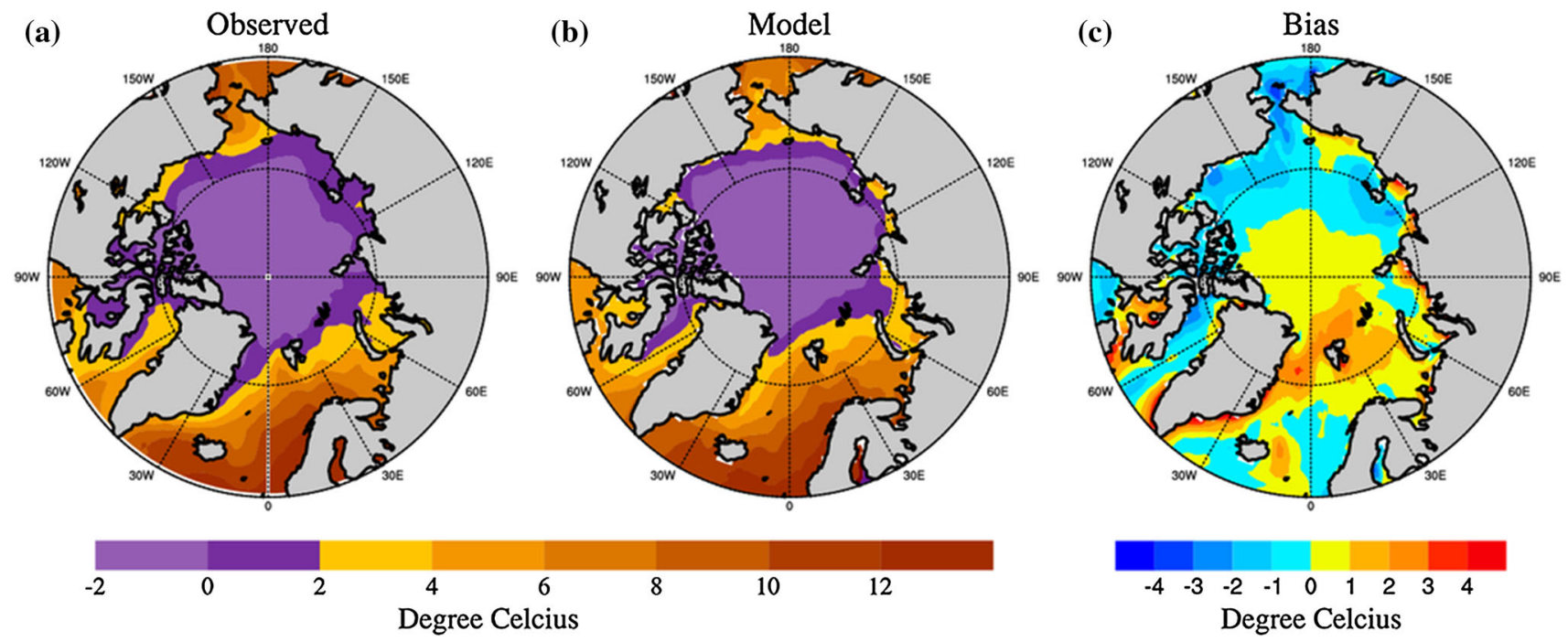

Figure 8. Mean SST (JAS) during 1996-2009.
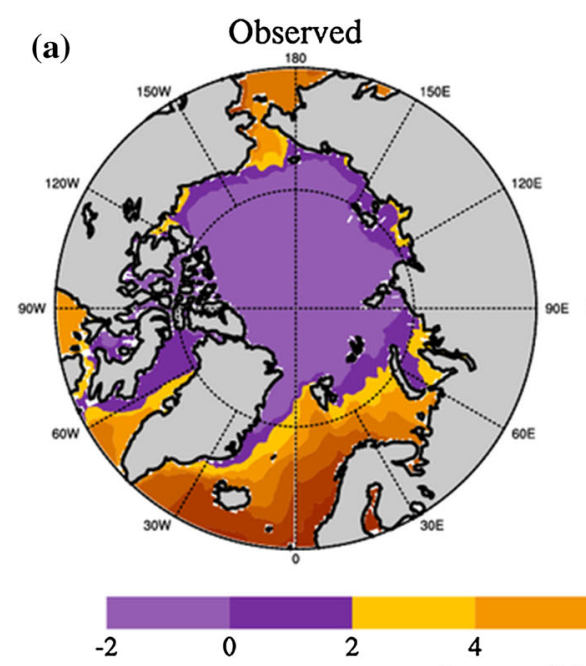

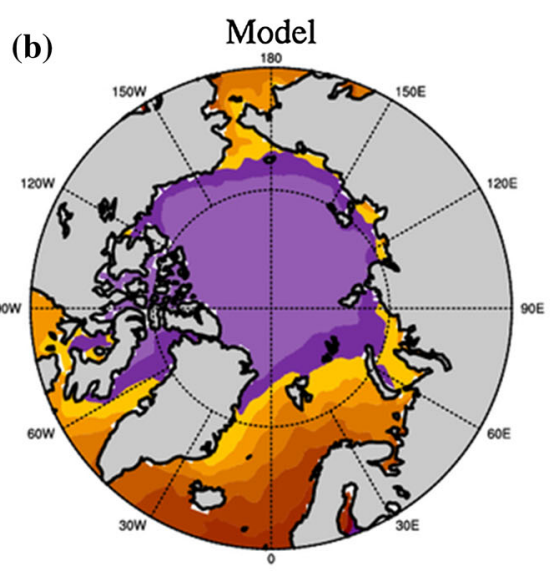

12

Degree Celcius

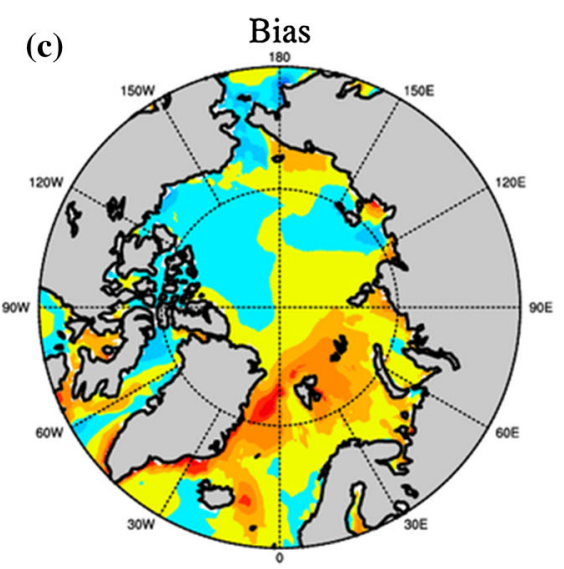

$\begin{array}{lllllllll}-4 & -3 & -2 & -1 & 0 & 1 & 2 & 3 & 4 \\ & \\ & \text { Degree Celcius }\end{array}$

Figure 9. Mean sub-surface temperature at 12 m (JAS) during 1996-2009. 

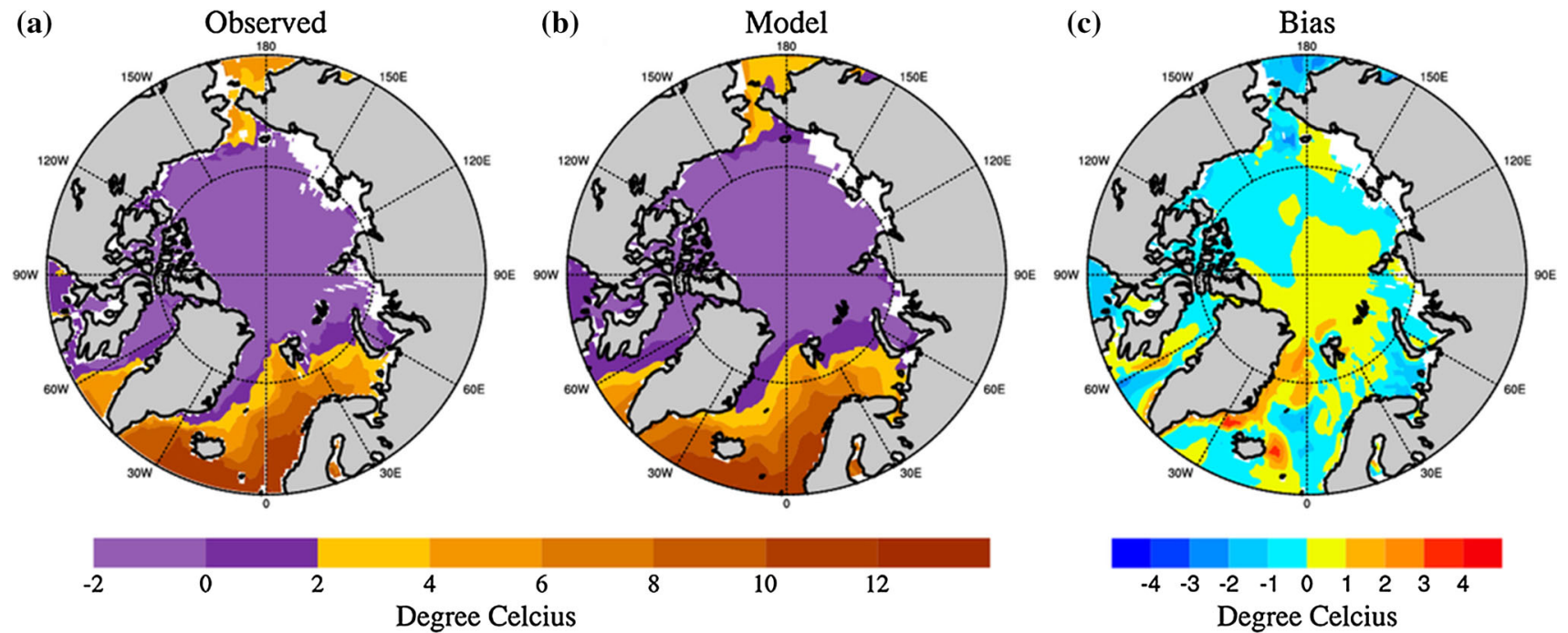

Figure 10. Mean sub-surface temperature at 30 m (JAS) during 1996-2009.

(a) Western Arctic (0:180W, 60N:90N)
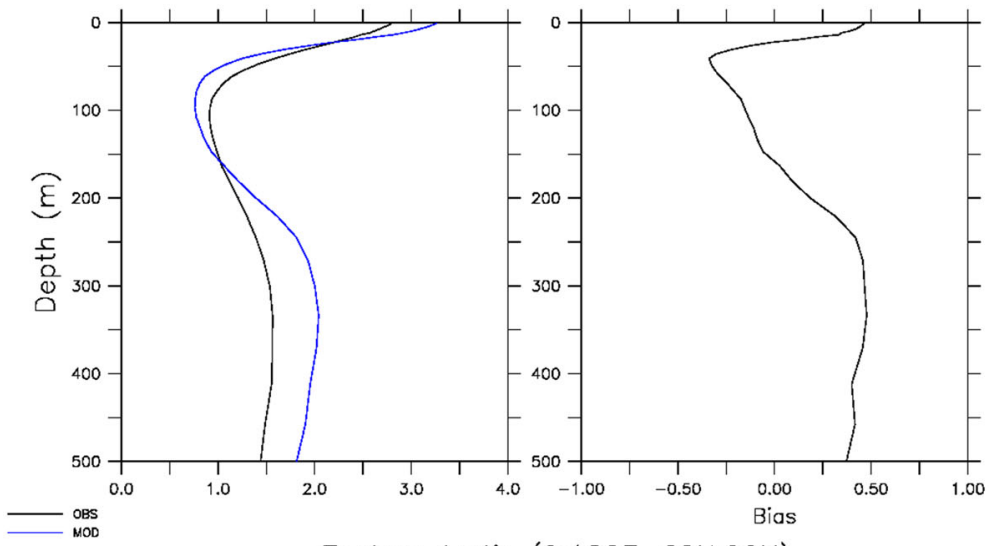

(b)

Eastern Arctic (0:180E, 60N:90N)

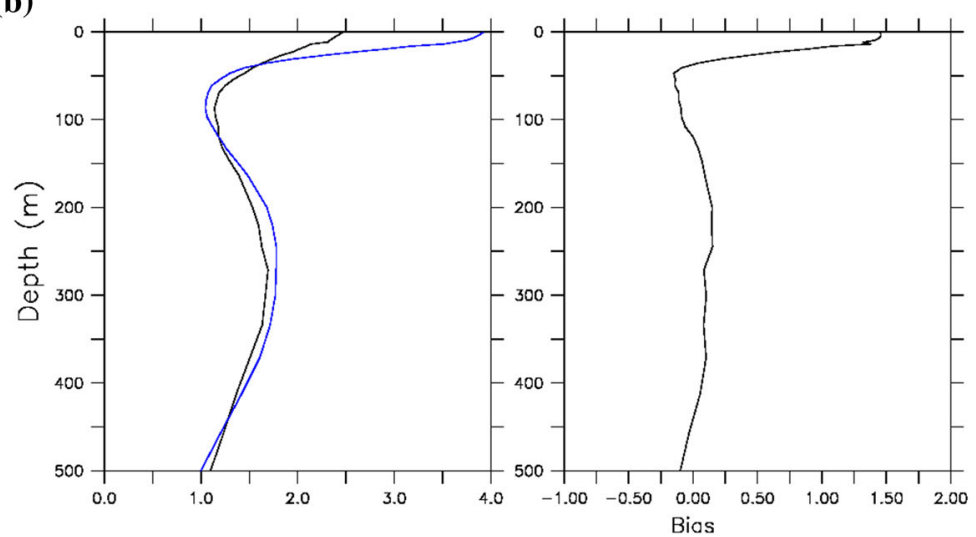

Figure 11. Mean vertical upper ocean (up to $500 \mathrm{~m}$ ) temperature (JAS) during 1996-2009.

thickness reasonably well, although both sea-ice concentration and thickness in model are underestimated. A positive (warm) bias is seen both in $2 \mathrm{~m}$ air temperature and SST, consistent with the negative sea-ice bias. The magnitude of the oceanic sub-surface warm biases is seen to be gradually decreasing with depth, but consistent with surface sea-ice biases. These analyses indicate a 

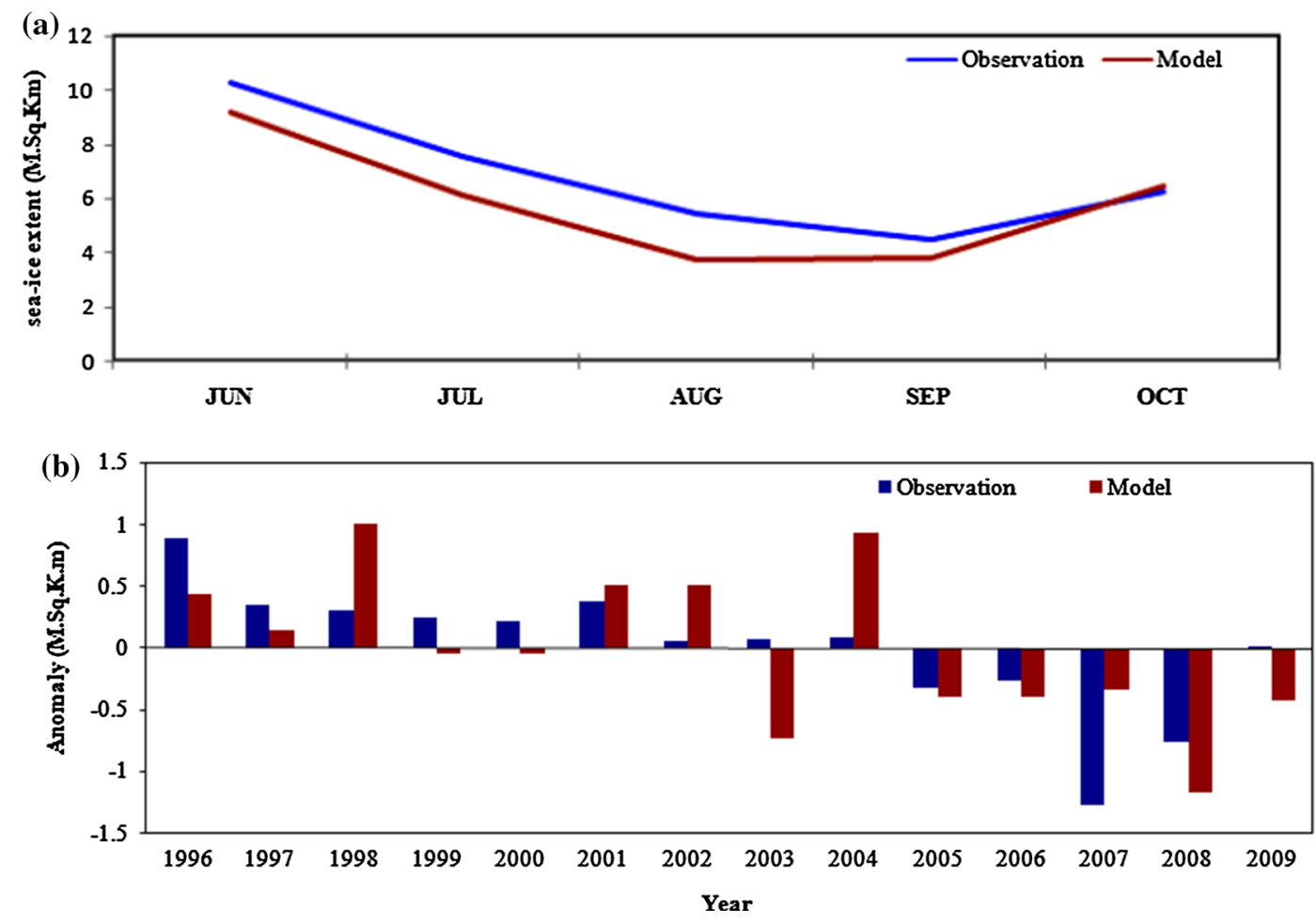

Figure 12. (a) Arctic mean sea-ice extent during 1996-2009. (b) Arctic mean sea-ice extent anomaly (JAS) during 1996-2009.

possibility of deeper warm sub-surface water in western Arctic Ocean sector (Pacific and Atlantic exchanges) affecting the negative biases in the seaice at surface. Biases in ocean surface currents and related ice drifts are not related to atmospheric winds biases. The model is able to simulate reasonably well the summer sea-ice melting process and its inter-annual variability, and has useable skill for application purpose.

Inter-comparison of sea-ice related parameters from ocean re-analysis and satellite data indicate some uncertainty about sea-ice concentration in observations (Saheed et al. 2016; Tietsche et al. 2017). There could as well be uncertainty in model simulations, coming from uncertainty in initial conditions, model formulation and representation of the physical processes in the model. Figure S1 (supplementary figure) shows the bias in model for sea-ice concentration compared to NSIDC observed dataset. The nature of bias is similar, but the magnitude is slightly different. In future model runs with few ensemble members will indicate the uncertainty in simulations. As the models are improving gradually, the re-analysis products are becoming better. At the Met Office, UK, new version of seaice, coupled model and its seasonal forecast version have been recently implemented (Maclachlan et al.
2015; Rae et al. 2015; Williams et al. 2015). It will be interesting to examine the polar sea-ice representation and related processes in these models. New types of matrices have been identified to diagnose the three dimensional sea-ice biases in models, which will reveal the deficiencies and links in the processes of Arctic (Dukhovskoy et al. 2015). A coordinated modeling experiment has been proposed to study the climate response function (Marshall et al. 2017) for the Arctic Ocean across a number of Arctic models, which will give better insight into the impact of model resolution, formulation and parameterization.

\section{Acknowledgements}

ORAP5 ocean re-analysis dataset was taken from http://marine.copernicus.eu. ERA Interim reanalysis was taken from ECMWF. HadISST data was taken from Hadley center, UK. GIOMAS observed sea-ice datasets were taken from Polar Science Centre, University of Washington, USA. The NEMO ocean model is part of NEMO consortium. CICE model was taken from Los Alamos National Laboratory sea-ice model repository. The NCMRWF component of the work is done under MoES Belmont Forum project BITMAP. We are 
thankful to two anonymous reviewers for their useful comments and suggestions.

\section{References}

Arribas A, Glover M, Maidens A, Peterson K, Gordon M, MacLachlan C, Graham R, Fereday D, Camp J, Scaife A A, Xavier P, McLean P, Colman A and Cusack S 2011 The GloSea4 ensemble prediction system for seasonal forecasting; Mon. Wea. Rev. 139 1891-1910, https://doi.org/10. 1175/2010MWR3615.1.

Balmaseda M A, Mogensen K and Weaver A T 2013 Evaluation of the ECMWF ocean reanalysis system ORAS4; Quart. J. Roy. Meteorol. Soc. 139 1132-1161, https://doi. org/10.1002/qj.2063.

Bitz C M and Lipscomb W H 1999 An energyconserving thermodynamic model of sea ice; J. Geophys. Res. Ocean 104 15669-15677, https://doi.org/10.1029/ 1999JC900100.

Cassano E N, Cassano J J, Higgins M E and Serreze M C 2014 Atmospheric impacts of an Arctic sea ice minimum as seen in the community atmosphere model; Int. J. Climatol. 34 766-779, https://doi.org/10.1002/joc.3723.

Cohen J, Screen J A, Furtado J C, Barlow M, Whittleston D, Coumou D, Francis J, Dethloff K, Entekhabi D, Overland J and Jones J 2014 Mid-latitude weather; Nat. Publ. Gr. 7 627-637, https://doi.org/10.1038/ngeo2234.

Comiso J C 2006 Abrupt decline in the Arctic winter sea ice cover; Geophys. Res. Lett. 33 1-5, https://doi.org/10. 1029/2006GL027341.

Day J J, Tietsche S, Collins M, Goessling H F, Guemas V, Guillory A, Hurlin W J, Ishii M, Keeley S P E, Matei D, Msadek R, Sigmond M, Tatebe H and Hawkins E 2016 The Arctic predictability and prediction on seasonalto-interannual TimEscales (APPOSITE) dataset version 1; Geosci. Model Dev. 9 2255-2270, https://doi.org/10. 5194/gmd-9-2255-2016.

Dee D P, Uppala S M, Simmons A J, Berrisford P, Poli P, Kobayashi S, Andrae U, Balmaseda A, Balsamo G, Bauer P, Bechtold P, Beljaars A C M, van de Berg L, Bidlot J, Bormann N, Delsol C, Dragani R, Fuentes M, Geer A J, Haimberger L, Healy S B, Hersbach H, Holm E V, Isaksen L, Kallberg P, Kohler M, Matricardi M, McNally A P, Monge-Sanz B M, Morcrette J J, Park B K, Peubey C, de Rosnay P, Tavolato C, Thepaut J N and Vitart F 2011 The ERA-Interim reanalysis: Configuration and performance of the data assimilation system; Quart. J. Roy. Meteorol. Soc. 137 553-597, https://doi.org/10.1002/qj.828.

Deser C and Teng H 2008 Evolution of Arctic sea ice concentration trends and the role of atmospheric circulation forcing, 1979-2007; Geophys. Res. Lett. 35 1-5, https:// doi.org/10.1029/2007GL032023.

Dukhovskoy, Dmitry S, Ubnoske J, Wrigglesworth E B, Hannah R and Hiester A P 2015 Skillmetrics for evaluation and comparison of sea icemodels; J. Geophys. Res. Ocean 132 1-17, https://doi.org/10.1002/2014JC010320.

Feltham D 2015 Arctic sea ice reduction: The evidence, models and impacts; Phil. Trans. Roy. Soc. A 373 1-3, https://doi.org/10.1098/rsta.2014.0171.
Gordon C, Cooper C, Senior C A, Banks H, Gregory J M, Johns T C, Mitchell J F B and Wood R A 2000 The simulation of SST, sea ice extents and ocean heat transports in a version of the Hadley centre coupled model without flux adjustments; Clim. Dyn. 16 147-168, https://doi.org/10. $1007 / \mathrm{s} 003820050010$.

Henderson G R, Barrett B S and Lafleur M D 2014 Arctic sea ice and the Madden-Julian Oscillation (MJO); Clim. Dyn. 43 2185-2196, https://doi.org/10.1007/ s00382-013-2043-y.

Hewitt H T, Copsey D, Culverwell I D, Harris C M, Hill R S R, Keen A B, McLaren A J and Hunke E C 2011 Design and implementation of the infrastructure of HadGEM3: The next-generation Met Office climate modelling system; Geosci. Model Dev. 4 223-253, https://doi.org/10.5194/ gmd-4-223-2011.

Hewitt H T, Ridley J K, Keen A B, West A E, Peterson K A, Rae J G L, Milton S M and Bacon S 2015 A seamless approach to understanding and predicting Arctic sea ice in Met Office Modelling systems; Phil. Trans. Roy. Soc. A 373 20140161, https://doi.org/10.1098/rsta.2014. 0161.

Hunke E C and Lipscomb W H 2010 CICE: The Los Alamos sea ice model documentation and software user's manual version 4.1 LA-CC-06-012; Los Alamos Natl. Lab., 1-76.

Johns T C, Durman C F, Banks H T, Roberts M J, McLaren A J, Ridley J K, Senior C A, Williams K D, Jones A, Rickard G J, Cusack S, Ingram W J, Crucifix M, Sexton D M H, Joshi M M, Dong B W, Spencer H, Hill R S R, Gregory J M, Keen A B, Pardaens A K, Lowe J A, BodasSalcedo A, Stark S and Searl Y 2006 The new Hadley centre climate model (HadGEM1): Evaluation of coupled simulations; J. Clim. 19 1327-1353, https://doi.org/10. 1175/JCLI3712.1.

Keen A B, Hewitt H T and Ridley J K 2013 A case study of a modelled episode of low Arctic sea ice; Clim. Dyn. 41(5-6) 1229-1244, https://doi.org/10.1007/ s00382-013-1679-y.

Krishnamurti T N, Krishnamurti R, Das S, Kumar V, Jayakumar A and Simon A 2014 A pathway connecting the monsoonal heating to the rapid Arctic ice melt; J. Atmos. Sci. 72 5-34, https://doi.org/10.1175/ JAS-D-14-0004.1.

Lipscomb W H and Hunke E C 2004 Modeling sea ice transport using incremental remapping; Mon. Wea. Rev. 132 1341-1354, https://doi.org/10.1175/1520-0493.

Liu J, Curry J A and Hu Y 2004 Recent Arctic sea ice variability: Connections to the Arctic oscillation and the ENSO; Geophys. Res. Lett. 31 2-5, https://doi.org/10. 1029/2004GL019858.

Maclachlan C, Arribas A, Peterson K A, Maidens A, Fereday D, Scaife A A, Gordon M, Vellinga M, Williams A, Comer R E, Camp J, Xavier P and Madec G 2015 Global seasonal forecast system version 5 (GloSea5): A high-resolution seasonal forecast system; Quart. J. Roy. Meteorol. Soc. 141 1072-1084, https://doi.org/10.1002/qj.2396.

McLaren A J, Banks H T, Durman C F, Gregory J M, Johns T C, Keen A B, Ridley J K, Roberts M J, Lipscomb W, Connolley W and Laxon S 2006 Evaluation of the sea ice simulation in a new atmosphere-ocean coupled climate model (HadGEM1); J. Geophys. Res. Oceans 111 C12014, https://doi.org/10.1029/2005JC003033. 
Madec G and the NEMO team 2008 NEMO ocean engine. Note du Pôle de modélisation', Institut Pierre-Simon Laplace (IPSL), France, No 27, ISSN No 1288-161.

Marshall J, Scott J and Proshutinsky A 2017 Climate response functions for the Arctic Ocean: A proposed coordinated modeling experiment; Geosci. Model Dev. Discuss. 1-25, https://doi.org/10.5194/gmd-2016-316.

Mitra A K, Rajagopal E N, Iyengar G R, Mahapatra D K, Momin I M, Gera A, Sharma K, George J P, Ashrit R, Dasgupta M, Mohandas S, Prasad V S, Basu S, Arribas A, Milton S F, Martin G M, Barker D and Martin M 2013 Prediction of monsoon using a seamless coupled modelling system; Curr. Sci. 104 13691379.

Parkinson C L and Cavalieri D J 2012 Antarctic sea ice variability and trends 1979-2010; Cryosphere 6 871-880, https://doi.org/10.5194/tc-6-871-2012.

Parkinson C L and DiGirolamo N E 2016 New visualizations highlight new information on the contrasting Arctic and Antarctic sea-ice trends since the late 1970's; Remote Sens. Environ. 183 198-204, https://doi.org/10.1016/j. rse.2016.05.020.

Pemberton P, Löptien U, Hordoir R, Höglund A, Schimanke S and Axell L 2017 Ocean-sea-ice model setup for the North sea and Baltic sea; Geosci. Model Dev. 10 31053123.

Peterson K A, Arribas A, Hewitt H T, Keen A B, Lea D J and McLaren A J 2015 Assessing the forecast skill of Arctic sea ice extent in the GloSea4 seasonal prediction system; Clim. Dyn. 44(1-2) 147-162, https://doi.org/10. 1007/s00382-014-2190-9.

Petrie R E, Shaffrey L C and Sutton R T 2015 Atmospheric response in summer linked to recent Arctic sea ice loss; Quart. J. Roy. Meteorol. Soc. 141 2070-2076, https:// doi.org/10.1002/qj.2502.

Rae J G L, Hewitt H T, Keen A B, Ridley J K, Edwards J M and Harris C M 2014 A sensitivity study of the sea ice simulation in the global coupled climate model, HadGEM3; Ocean Model $\mathbf{7 4}$ 60-76, https://doi.org/10. 1016/j.ocemod.2013.12.003.

Rae J G L, Hewitt H T, Keen A B, Ridley J K, West A E, Harris C M, Hunke E C and Walters D N 2015 Development of the global sea ice 6.0 CICE configuration for the met office global coupled model; Geosci. Model Dev. 8 2221-2230, https://doi.org/10.5194/gmd-8-2221-2015.

Rayner N A, Parker D E, Horton E B, Folland C K, Alexander L V, Rowell D P, Kent E C and Kaplan A 2003 Global analyses of sea surface temperature, sea ice, and night marine air temperature since the late nineteenth century; J. Geophys. Res. 108 4407, https://doi.org/10. 1029/2002JD002670.

Reynolds R W, Smith T M, Liu C, Chelton D B, Casey K S and Schlax M G 2007 Dailyhigh-resolution-blended analyses for sea surface temperature; J. Clim. 20 5473-5496, https://doi.org/10.1175/2007JCLI1824.1.

Rinke A, Dethloff K, Dorn W, Handorf D and Moore J C 2013 Simulated Arctic atmospheric feedbacks associated with late summer sea ice anomalies; J. Geophys. Res. Atmos. 118 7698-7714, https://doi.org/10.1002/ jgrd.50584.

Saheed P P, Mitra A K, Momin I M, Mahapatra D and Rajagopal E N 2016 Satellite information of sea ice for model validation; In: Proceedings of Land Surface and Cryosphere Remote Sensing, 98772G, https://doi.org/10. $1117 / 12.2223513$

Screen J A and Francis J A 2016 Contribution of sea-ice loss to Arctic amplification is regulated by Pacific Ocean decadal variability; Nat. Clim. Chang. 6 856-860, https:// doi.org/10.1038/nclimate3011.

Semtner A J 1976 A model for the thermodynamic growth of sea ice in numerical investigations of climate; J. Phys. Oceanogr., https://doi.org/10.1175/1520-0485(1976).

Serreze M C, Marika M and Holland J S 2007 Perspectives on the Arctic's shrinking sea-ice cover; Science 3151533 1537.

Serreze M C and Stroeve J 2015 Arctic sea ice trends, variability and implications for seasonal ice forecasting; Phil. Trans. Roy. Soc. A 373 20140159, https://doi.org/10. 1098/rsta.2014.0159.

Thorndike A S, Rothrock D A, Maykut G A and Colony R 1975 The thickness distribution of sea-ice; J. Geophys. Res. 80(33) 4501-4513.

Tietsche S, Balmaseda M A, Zuo H and Mogensen K 2017 Arctic sea ice in the global eddy-permitting ocean reanalysis ORAP5; Clim. Dyn. 49 775-789, https://doi.org/10. 1007/s00382-015-2673-3.

Tietsche S, Day J J, Guemas V, Hurlin W J, Keeley S P E, Matei D, Msadek R, Collins M and Hawkins E 2014 Seasonal to interannual Arctic sea ice predictability in current global climate model; Geophys. Monogr. Ser. 41 1035-1043, https://doi.org/10.1002/2013GL058755.

Vihma T 2014 Effects of Arctic sea ice decline on weather and climate: A review; Surv. Geophys. 35 1175-1214, https:// doi.org/10.1007/s10712-014-9284-0.

Williams K D, Harris C M, Camp J, Comer R E, Copsey D, Fereday D, Graham T, Hill R, Hinton T, Hyder P, Ineson S, Masato G, Milton S F, Roberts M J, Rowell D P, Sanchez C, Shelly A, Sinha B, Walters D N, West A, Woollings T and Xavier P K 2015 The Met Office global coupled model 2.0 (GC2) configuration; Geosci. Model Dev. 8 1509-1524, https://doi.org/ 10.5194/gmd-88-1509-2015.

Zhang J L and Rothrock D A 2003 Modleing global sea ice with a thickness and enthalpy distribution model in generalized curvilinear coordinates; Mon. Wea. Rev. 131 845-861. 